\title{
Ensino do inglês em contexto indígena bi/tri/plurilíngue intercultural
}

\author{
Rodrigo Guimarães Prudente Marquez Cotrim ${ }^{1}$
}

\section{RESUMO}

Este trabalho visa apresentar uma experiência de diálogo pedagógico e linguístico no processo de ensino e de aprendizagem do inglês, em contexto educativo bilíngue intercultural, em salas de aula plurilíngues, de um curso de licenciatura intercultural de formação superior de professores indígenas. Para este processo, dentro do qual várias línguas coexistem no espaço de sala de aula, foi necessário o desenvolvimento de uma base de conhecimento bi/tri/plurilíngue. Esta base inclui desde a pesquisa e a seleção de gêneros textuais escritos, orais e semióticos do universo indígena, produzidos e mediados em inglês, ao estudo, documentação e análise dos sons e de processos de formação de palavras nas línguas indígenas envolvidas, no inglês e no português, a fim de permitir a reflexão sobre a situação sociolinguística, sobre a troca de conhecimentos e sobre o uso de pistas translinguísticas e interculturais nesse processo de ensino e aprendizagem da "leitura" do e em inglês. Apresento, assim, parte do trabalho realizado, do material produzido e de algumas pistas de leitura, elaborada em coautoria com professores e professoras indígenas, e desenvolvidas sobre o continuum "contextotexto-palavras-sons-contexto", proposta freiriana para o trabalho de "leitura" empregada nas aulas de língua inglesa. Como recorte dessas pistas e da base desenvolvida, faço um esboço dos temas contextuais e dos gêneros textuais trabalhados, bem como apresento um panorama da discussão estabelecida nas aulas de inglês sobre a formação das palavras - com enfoque nos empréstimos linguísticos e em alguns processos derivacionais nas línguas envolvidas -, passando à reflexão sobre o ensino dos sons do inglês em contexto de interculturalidade e de translinguagem.

PALAVRAS-CHAVE: Educação indígena. Ensino de Inglês. Interculturalidade. Translinguagem.

\section{English teaching in an intercultural indigenous bi/tri/multilingual context}

\section{ABSTRACT}

This paper aims to present a teaching and language dialogue in the process of teaching and learning English in an intercultural bilingual educational context, in multilingual classrooms, at an Intercultural higher education course for indigenous teachers. For this process, within which several languages coexist in the classroom space, it was necessary to develop a bi/tri/multilingual knowledge base. In this base it is included, from the research and selection of written, oral and semiotic textual genres of the indigenous universe, produced and mediated in English, to the study, documentation and analysis of sounds and processes of word formation and sentences, in the indigenous languages involved, in English, and Portuguese, in order to allow reflection on the sociolinguistic situation, on the exchange of knowledge and on the use of translinguistic and intercultural clues in the teaching and learning

${ }^{1}$ Universidade Estadual de Goiás (UEG), Pirenópolis, Goiás. E-mail: rodprudente@ gmail.com. 
process of "reading" in and on English. Therefore, I present some methodological clues, elaborated in co-authorship with indigenous teachers, especially during Intercultural English I to Intercultural English VIII classes, in order to (re)think(ing) the process of teaching and learning English, especially in contexts of interculturality and plurilingualism and, thus, of constant interactions, besides intercultural and translinguistic, and identity performances.

KEYWORDS: English teaching. Intercultural English. Indigenous education. Translingualism.

\section{Apresentação}

Este artigo objetiva apresentar um breve panorama de uma experiência de quase dez anos com o ensino intercultural do inglês, em um contexto de educação superior intercultural indígena, com falantes bi/trilíngues e/ou bidialetais e em salas de aula plurilíngues. Este processo de ensino e aprendizagem do inglês em um "contexto indígena" só se tornou possível baseando-se em uma perspectiva pedagógica - o que se tornaria, também, metodológica - bi/tri/plurilíngue intercultural, realizado com professores, acadêmicos, pesquisadores e sabedores indígenas sobretudo, mas, também, não indígenas. Pauta-se, assim, na metodologia do diálogo contextual e intercultural de conhecimentos que emergem do contato entre diferentes povos e suas línguas e, portanto, de suas manifestações socioculturais, de suas expressões artísticas, bem como de seus discursos, frases, palavras e sons.

Por nossa sala de aula de Inglês Intercultural - estudo complementar contemplado na matriz de um curso de Licenciatura Intercultural Indígena, destinado a Povos da região etnoeducacional Araguaia-Tocantins - ser marcadamente plurilíngue, impõe-se, metodologicamente, um “diálogo das línguas”, de forma contextualizada. As línguas e culturas envolvidas são línguas indígenas dos troncos linguísticos: Macro-Jê, da família Jê (Akwẽ-Xerente, Apinajé, Canela, Gavião, Krahô, Krikati, Tapuia) e da família Karajá (Karajá, Karajá-Xambioá e Javaé), bem como línguas-culturas do tronco Tupi, da família Tupi-Guarani (Guajajara e Tapirapé, do subgrupo 4, e o Guarani-Mbyá, do subgrupo 1) (cf. RODRIGUES, 1986), além, evidentemente, das línguas portuguesa e inglesa.

A proposta de ensino de inglês aqui desenvolvida pauta-se nos princípios da interculturalidade e da diversidade. Pimentel da Silva e Rocha (2006), abordando sobre a educação bilíngue entre povos indígenas brasileiros, argumentam que, no campo da educação, a interculturalidade é um processo de diálogo (entre teoria e prática, de significações, de "cultura", de hábitos e modos de vida, de técnicas), estando o educando e sua língua no centro desse diálogo de trocas de saberes. Ressalta-se que a educação bilíngue intercultural geralmente pressupõe o ensino e a aprendizagem de línguas. Neste contexto, visa-se uma 
abordagem que se situe na valorização da diferença e do diálogo entre diversos grupos socioculturais e linguísticos envolvidos, atentando-se às relações interculturais, à situação sociolinguística e à valorização das línguas de todos os participantes. Neste sentido, Tubino (2005, p. 5) alerta que no ensino bilíngue, "la asimetría entre las lenguas y las culturas es una adversidad que dificulta el diálogo y la comunicación intercultural". Concordante a isso, Pimentel da Silva (2011) afirma que,

No contexto de ensino de segunda língua e em segunda língua, a não valorização da língua materna / originária, coloca-a numa concepção de bilinguismo subtrativo. Isso contraria a ideia da educação bilíngue intercultural. É importante lembrar também da variedade linguística das comunidades. Considerar a realidade sociolinguística delas: se bilíngues, monolíngues, trilíngues, e pensar numa política de ensino das línguas, mas também nas línguas (PIMENTEL DA SILVA, 2011, p. 58).

Conforme alerta Pimentel da Silva (2011, p. 8), na educação escolar indígena os conhecimentos indígenas, sua língua e sua cultura, todavia "são tratados de forma periférica, fazendo parte de projetos pedagógicos pensados em uma visão monolíngue e monocultural”. Neste ponto, a educação intercultural, aliada ao ensino de línguas, relaciona-se diretamente com os professores que procuram instrumentos concretos "com o objetivo de colocar no centro dos processos educativos o tema da diversidade e das competências interculturais" (GODOY, 2001, p. 237), dentre elas, a diversidade de língua(gens), de performances sociais e culturais, de modos de agir e de pensar o mundo. Em outras palavras, conforme reforça a fala do professor Kbasdimẽkwa-Xerente, uma "educação bilíngue intercultural para ser usada no nosso conhecimento, nossa língua, nossa escrita, nossa escola e nossa cultura", reconhecendo e fazendo uso de saberes próprios e saberes compartilhados. Busca-se, dessa forma, em uma concepção dialógica de educação bilíngue intercultural, levar em conta propostas de cidadania, de troca de conhecimentos, de interculturalidade, de sustentabilidade, de reconhecimento e de respeito à diferença e à diversidade (de línguas, culturas, identidades, técnicas, etc.) considerando, também, as propostas de desenvolvimento da comunicação intercultural e da diversidade linguístico-cultural no Brasil ${ }^{2}$ e no mundo ${ }^{3}$.

\footnotetext{
${ }^{2}$ Vide, por exemplo, a Declaração de Recife de 1987 da Associação Internacional para o Desenvolvimento da Comunicação Intercultural na Declaração Universal dos Direitos Linguísticos (1996).

3 Vide, por exemplo, a Carta das línguas regionais ou minoritárias, assinada em 1992 (disponível no http://conventions.coe.int); a Recomendação 1383, publicada em 1998, que trata da "Diversidade linguística" e a Recomendação 1539, criada em 2001, em referência ao “Ano Europeu das Línguas 2001”, ambas promulgadas pelo Parlamento do Conselho da Europa (disponíveis no http://assembly.coe.int/).
} 
Faço aqui um recorte de algumas estratégias utilizadas neste processo de ensino e de aprendizagem do inglês. Chamo destaque para a elaboração de uma base de conhecimentos bi/tri/plurilíngue intercultural, ao desenvolvimento de pistas de 'leitura', ao uso de temas contextualizados à realidade indígena, e propagados em inglês, bem como ao uso das línguas indígenas brasileiras no contexto de ensino público superior, incluindo-se nas aulas de língua inglesa. Como recorte dessas pistas de leitura e da base de conhecimentos elaboradas, faço um esboço dos temas contextuais e dos gêneros textuais trabalhados, bem como apresento um panorama da discussão estabelecida nas aulas de inglês sobre a formação das palavras - com enfoque nos empréstimos linguísticos e em alguns processos derivacionais nas línguas envolvidas -, passando à reflexão sobre o ensino dos sons do inglês em contexto bi/tri/plurilíngue intercultural e, portanto, pautada nas constantes interações de interculturalidade e de translinguagem. Exemplificações em línguas indígenas, em português e em inglês foram dadas, ora transcritas fonologicamente, ora grafemicamente, por questões pedagógicas.

\section{Base de conhecimento do Inglês Intercultural}

A elaboração de uma base de conhecimento, na qual se incluem textos - escritos, orais e semióticos - em inglês, português e em línguas indígenas brasileiras, assim como o desenvolvimento de estratégias para o ensino do inglês no contexto plurilíngue intercultural apresentado, foram pautados, sobretudo, nas constantes trocas de conhecimentos interculturais e translinguísticos realizadas em sala de aula de Inglês Intercultural como, também, durante seminários, oficinas de produção de material didático, orientações de monografia e de projetos extraescolares realizados no âmbito do curso de Licenciatura Intercultural. Foram também realizadas pesquisas em teses, dissertações, artigos, livros e em documentos históricos, reportagens, revistas e redes sociais, cujas temáticas abordam, sobretudo, a língua inglesa e as línguas e os movimentos interculturais indígenas brasileiros.

Como os atores e autores deste processo são diversos, assim como suas línguas e culturas, apresento aqui, com mais enfoque, o diálogo estabelecido entre a língua inglesa e a língua dos professores Xerente, com os quais também trabalhamos durante o estágio pedagógico, na produção de material didático e na escrita de monografias e de artigos acadêmicos. Não obstante, isso não implica, no presente artigo, a exclusão de exemplos reais emergidos em sala de aula, das e nas línguas indígenas em diálogo com a língua inglesa. 
Para a elaboração de uma base de conhecimento bi/tri/plurilíngue que possibilitasse a intercompreensão mais simétrica entre as línguas envolvidas durante o processo de ensino do Inglês Intercultural, fez-se necessária a revisão de pelo menos três línguas que compõem o ambiente de sala de aula do Inglês Intercultural: o Xerente (TUGGIA, 1851; MATTOS, 1973; KRIEGER E KRIEGER, 1994; BRAGGIO, 2005b, 2010; SOUZA, 2008; ANDRADE, 2008; SIQUEIRA, 2003; MESQUITA, 2009; SOUSA FILHO, 2007), o Inglês (ODLIN, 1996; QUIRK ET. ALL, 1997; LONGMAN, 1997; STEINBERG, 2003, 2006; CRYSTAL, 2001, 2005, 2006; LAMPRECHT et al., 2009; COTRIM, 2010, 2012; COTRIM e OLIVEIRA, 2010) e o Português (CRISTÓFARO SILVA, 2002; KEHDI, 2003, 2007, NASCIMENTO, 2010; 2012), para citar alguns exemplos. A elaboração de uma base de conhecimentos bi/tri/plurilíngue possibilitou o desenvolvimento e a aplicação de pistas de 'leitura' no ensino e na aprendizagem da língua inglesa, em diálogo com os Povos e as línguas indígenas presentes no espaço de sala de aula, sem perder de vista a interculturalidade inerente aos contextos de plurilinguagens.

Para partirmos da leitura do contexto à leitura do texto, desenvolvemos algumas pistas que foram sendo utilizadas durante as aulas de "leitura" do Inglês Intercultural, fundadas em uma pedagogia bi/tri/plurilíngue intercultural como, por exemplo, o uso de (1) línguas indígenas que se encontram em contato e do(s) português(es) brasileiro (em numa perspectiva bilíngue intercultural); (2) conhecimento intracultural e intercultural; (3) temas contextuais; (4) (re)conhecimento de gêneros textuais e discursivos, escritos, orais e semióticos; (5) formação de palavras em uma perspectiva bi/tri/plurilíngue intercultural, com ênfase em alguns processos de derivação e nos neologismos (empréstimos linguísticos e metáforas), posto que podem revelar significados social, cultural, econômico, etc., mais amplos; (6) sons das línguas em uma perspectiva bi/tri/plurilíngue intercultural; (7) tradução, numa perspectiva bi/trilíngue intercultural; (8) uso de novas tecnologias (tecnologias de voz, escrita e imagem); (9) recursividade: "repetição" característica da oralidade e de gêneros discursivos orais e que pode ser utilizada como pista de leitura em que temas se repetem de forma lógica e contextualizada; (10) releitura e meta-leitura, ou seja, refletir sobre o processo de leitura à medida em que se lê o texto e se compreende a sua forma, a sua função, e reconhece seus atores e autores, bem como o seu contexto, a sua "(con)textualidade". 4

\footnotetext{
${ }^{4}$ Apesar de que o nosso objetivo seja pautar em uma visão intercultural e não instrumental do inglês, utilizamos também de algumas estratégias de leitura instrumental do inglês já bem conhecidas na literatura (c.f. SOUZA et $a l .$, 2005) e que, portanto, não serão aqui abordadas, mas que podem ser usadas em qualquer situação e nível de ensino como método auxiliar do inglês intercultural (1) o uso de cognatos, i.e., palavras que geralmente possuem uma raiz latina ou grega e que possuem o mesmo significado em Inglês e em Português, bem como o uso de 
Como recorte do presente artigo, a seguir, apresento um panorama do trabalho realizado nas aulas de Inglês Intercultural, dividido em quatro partes, utilizando-se da base de conhecimentos elaborada: na primeira, do contexto ao texto (item 2.1), apresento parte do trabalho realizado com gêneros textuais, pautados em temas contextuais. Em seguida, em do contexto ao texto às palavras (2.2), abordo o uso de alguns processos de formação de palavras - neologismo/empréstimos e alguns processos derivacionais comuns às línguas em contato na aula de língua inglesa - a fim de estabelecer as relações entre a leitura do texto em inglês e o entendimento do conjunto lexical que o forma, bem como a leitura das palavras no contexto do texto e no contexto do acadêmico indígena, seja em níveis mais lexical, gramatical e/ou pragmático. No item (2.3), do contexto ao texto às palavras aos sons, teço uma reflexão sobre o ensino dos sons do inglês em um contexto bi/tri/plurilíngue intercultural e, para tanto, estabeleço uma comparação entre os sons das consoantes e das vogais no Inglês, no Xerente e no Português, e reflito sobre sons iguais e diferentes que há no inglês e nas línguas indígenas presentes no Inglês Intercultural. Finalmente, em do contexto ao texto às palavras aos sons, à produção textual no Inglês Intercultural (2.4), apresento amostras da produção textual bi/tri/plurilíngue realizada por acadêmicos indígenas durante as aulas de inglês.

\footnotetext{
falsos-cognatos. (2) skimming (leitura rápida com o objetivo de buscar a ideia geral do texto e adquirir uma impressão geral sobre o seu assunto); (3) scanning (leitura rápida com o objetivo de procurar / selecionar uma informação específica do texto como, por exemplo, quando na leitura de um jornal, em que corremos os olhos para localizar aquilo que realmente nos interessa); (4) identificação de marcas tipográficas (recursos visuais como títulos e subtítulos, números, símbolos, letras maiúsculas, divisão do texto em parágrafos, letras especiais como negrito / itálico / sublinhado; material gráfico como tabelas, gráficos, fotos, desenhos, mapas, etc.); (5) palavras-chave e palavras repetidas, i.e., palavras que aparecem repetitivamente no texto e que geralmente são palavras com mais conteúdo lexical como verbos, substantivos e adjetivos; (6) uso do dicionário; (7) identificação de Nomes Próprios; (8) ativação do conhecimento prévio, i.e., resgate do conhecimento de mundo que o leitor já traz consigo desde o início de sua formação como ser social; (9) predição / advinhação, i.e., o ato de predizer ou inferir, sabendo-se que a aprendizagem pressupõe adivinhações e suposições que são confirmadas ao longo desse processo. Neste ponto, o leitor pode usar o seu conhecimento de mundo, o seu repertório linguístico, observar o contexto em que as palavras e as frases se inserem, bem como elementos não-linguísticos (gravuras, gráficos, tabelas, números, diagramas, etc.); (10) seletividade, i.e., o leitor seleciona, ao longo do texto, através da leitura de títulos, subtítulos, primeiros e últimos parágrafos, primeiras e últimas linhas de cada parágrafo, a informação desejada de acordo com seus objetivos de leitura; (11) identificação das funções retóricas do texto, ou seja, a maneira pela qual o autor do texto escolhe a sequência do texto, o que e como dizer. De acordo com o que o autor quer dizer, ele pode informar, narrar, definir, descrever, classificar, exemplificar, explicar, levantar hipóteses ou comparar, contrastar, argumentar, etc.; (12) identificação de afixos (sufixos, prefixos e infixos): esta estratégia auxilia o leitor a descobrir o significado de processos de derivação e de flexão de palavras, bem como a formação de neologismos e de empréstimos linguísticos.
} 


\section{Inglês Intercultural: do contexto ao texto às palavras aos sons}

Segundo Freire e Shor (1986), “desde muito pequenos aprendemos a entender o mundo que nos rodeia. Por isso, antes mesmo de aprender a ler e a escrever palavras e frases, já estamos 'lendo', bem ou mal, o mundo que nos cerca”. Os autores acrescentam que o ato de leitura pressupõe "descobrir a conexão entre o texto e o contexto do texto e também como vincular o texto/contexto com o meu contexto, o texto do leitor." (FREIRE; SHOR, 1986, p. $15)$.

Durante as aulas de inglês, pautamo-nos na visão de 'leitura' freiriana, a qual indica que "a compreensão do texto a ser alcançada por sua leitura crítica implica a percepção das relações entre o texto e o contexto" (FREIRE, 2000, p.11), em outras palavras, que "a leitura do mundo precede a da palavra e a leitura desta implica a continuidade da leitura daquela (IBIDEM, p. 20)". Busca-se, portanto, empregar o continuum contexto-texto-palavra-somcontexto, interpretação à proposta freiriana para o trabalho de "leitura" empregada nas aulas de língua inglesa, bem como para a elaboração da base de conhecimentos no contexto apresentado, o que implica, metodologicamente, um diálogo das línguas, de forma contextualizada.

(Re)conhecer o meu contexto e o contexto do outro em diálogo intercultural, bem como pensar o uso, a função e o ensino de línguas, no caso, a língua inglesa em contextos de interculturalidade, deverá ser uma ação levada a cabo concomitantemente ao ensino de línguas de forma geral. Essa premissa contextual servirá, por exemplo, quando no uso de pistas de leitura e de escrita de gêneros textuais e discursivos, ou no ensino e na aprendizagem de um conjunto significativo de palavras e de sons de primeiras, segundas ou terceiras línguas.

$\mathrm{Na}$ abordagem freiriana de 'leitura', dialoga-se, necessariamente, o contexto do leitor com o contexto do texto. Só depois de desvelados esses significados con(textuais), parte-se para a "palavra" e a associação de suas partes (PALAVRA - MORFEMA de composição, de derivação, de flexão) para, então, ir das palavras aos sons (MORFEMAS - FONEMAS GRAFEMAS), familiarizando e despertando a curiosidade dos alunos pela língua escrita e a sua relação com as palavras e os sons da fala, explorando o conhecimento das diversas manifestações da língua(gem). No Inglês Intercultural partimos, portanto, de temas contextualizados às realidades indígenas, fazendo uso de gêneros textuais escritos, orais e semióticos, em inglês, à medida em que analisamos, criticamente, contexto-texto-palavrassons-contexto. Da mesma forma, são trabalhadas a percepção sobre as seleções temáticas e 
lexicais (dos gêneros textuais), sobre o uso e a formação de palavras (com destaque, aqui, para os empréstimos linguísticos e para alguns processos de derivação) e sobre a consciência dos sons do inglês e das línguas indígenas em contato bi/tri/plurilíngue intercultural.

\subsection{Do contexto ao texto}

De forma a trabalhar o contexto do texto e o texto no contexto, exploramos o uso de "temas contextuais" e de gêneros textuais (escritos, orais e semióticos) que fazem interface com o universo indígena. $\mathrm{O}$ trabalho com temas contextuais pressupõe,

[...] a contextualização do conhecimento sem hierarquia das disciplinas, mas principalmente sem a hierarquia da colonialidade do saber. Ou seja, é o entendimento de que o conhecimento está em todos os lugares onde os diferentes povos e suas culturas se desenvolvem e, assim, são múltiplas as epistemes com seus muitos mundos de vida (PIMENTEL DA SILVA, 2011, p. 1).

Contextualizando o ensino do inglês nas relações interculturais que emergem neste contexto de diversidade de povos, de culturas e de plurilinguagens, nos atentamos, por exemplo, ao "discurso indígena" na mídia (internet, televisão, jornais impressos), na moda, no humor, na arte indígena, na comercialização de artesanatos indígenas no Brasil e no mundo, no tráfico de artesanatos indígenas brasileiros, na culinária, na música, na própria educação superior indígena, no ensino de inglês para indígenas (proposta, inclusive, pelo Ministério das Relações Exteriores, órgão do poder executivo brasileiro), na educação bilíngue intercultural, os quais se constituem como alguns dos "temas contextuais" que refletem o próprio contexto de ensino e de aprendizagem do Inglês Intercultural.

A estratégia de uso de temas contextualizados em determinada realidade indígena no ensino do inglês vem se mostrando como uma motivação para a 'leitura' das relações interculturais e intraculturais emergidas dentro e fora da sala de aula, bem como para o exercício das habilidades de leitura e de escrita em inglês, na mesma medida em que impacta positivamente no trabalho com o estudo das palavras e dos sons da língua inglesa. A Figura 1 e a Figura 2, a seguir, ilustram um dos temas contextuais trabalhados no Inglês Intercultural, "Indigenous art": 
Figura 1 - "Vogue Brazil catwalk with golden grass hats"

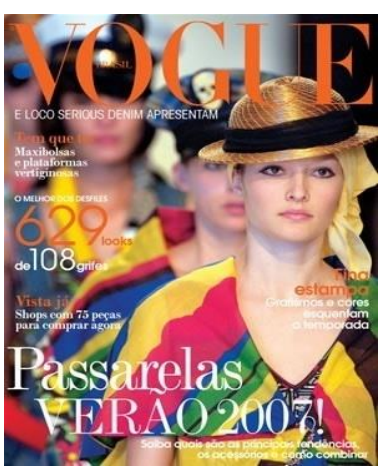

The famous magazine VOGUE in its Brazilian edition shows the designs of Alexandre Herchcovitch using in his fashion collection GOLDEN GRASS handmade hats that he has decorated.

Fonte: www.cartaeditorial.com.br.

Figura 2 - "Investigation of Illegal Brazilian Artifacts"

Special Agents and Brazil Delegation Investigate Illegal Artifacts

10 Region, January 31, 2005

Special agents of the United States met with two police investigator from Brazil in Sandusky, Ohio, to stop illegal trafficking in Brazilia native artifacts (indigenous artifacts)

The special agents' investigation uncovered more than 2,000 items illegally imported into the United States from Brazil. The items ha been purchased legally in Brazil and then sold here for thousands dollars above their original purchase prices.

Fonte: Ohio News (2005).

O uso de peças feitas em capim dourado e produzidas especialmente por populações indígenas e quilombolas da região Araguaia-Tocantins, vem sendo cada vez mais propagado pela mídia e pelo comércio. A Figura 1, foto de uma revista internacional de moda (Vogue), refere-se ao seu uso na moda, e traz como destaque a matéria de capa sobre uso de chapéus de capim dourado, "handmade" (feito à mão), exibidos por modelos brasileiras no desfile da coleção primavera-verão de 2007 do designer Alexandre Herchcovitch. A Figura 2 trata de uma matéria de jornal norte-americano denunciando o tráfico internacional de artesanatos indígenas brasileiros, vendidos a milhares de dólares nos Estados Unidos.

Exemplos de uso de referências indígenas, em especial, de artesanato indígena no contexto brasileiro são vários: A "ala capim dourado" fez sucesso no desfile da Mocidade Independente de Padre Miguel, no Carnaval de 2007 do Rio de Janeiro. Feixes de capim enfeitaram as fantasias. Bandas musicais brasileiras (Calypso), telenovelas (A Favorita, Araguaia) e programas de auditório televisivos (Raul Gil, Ana Hickmann) também exploram a arte de artefatos feitos de capim-dourado. Na cidade de Goiânia (Goiás), por exemplo, há, anualmente, uma feira internacional de arte, onde facilmente se encontra arte indígena brasileira. Outros exemplos são as exposições e feiras de artesanato indígena de Budapeste (“Exposição Índios do Brasil”) e de Milão. Não é difícil encontrar em qualquer aeroporto e rodoviária do País, bem como nos shoppings da cidade, peças indígenas e quilombolas feitas de capim dourado, buriti, tiririca, dentre vários outros tipos de sementes. A identidade dos produtores indígenas e quilombolas, no entanto, desaparece em todas elas.

Uma pista de 'leitura' importante neste processo de ensino do inglês intercultural, baseia-se na análise de gêneros textuais - com suas formas e funções que podem variar conforme o contexto sociocultural em que circulam - e de seu contexto de produção (quem, onde, como, quando, porquê, com que instrumentos, por quais meios). Dessa forma, 
pressupõe-se analisar o contexto do texto, ou seja, o seu contexto de produção e distribuição, o que certamente inclui seus atores e autores, bem como o uso de novas língua(gens) e tecnologias.

Quanto ao contexto, uma charge (gênero textual mais semiótico) ou uma publicidade (semiótico, oral e escrito) que faça alusão a povos indígenas brasileiros, e que seja produzida em língua inglesa, poderá suscitar a análise de contextos dos mais variados: desde identitário (expressão de gênero, raça/etnia, nacionalidade/territorialidade) - assim como a sua apropriação - a contextos sociocultural, sociolinguístico, socioeconômico, tecnológico, etc., dentre outros domínios em que nós, seres humanos, estamos inseridos. A seguir, a charge de um jornal (de papel) goiano, de grande circulação (Figura 3), e a publicidade online de um site de vendas (Figura 4) ilustram o uso de referências indígenas e o uso da língua inglesa:

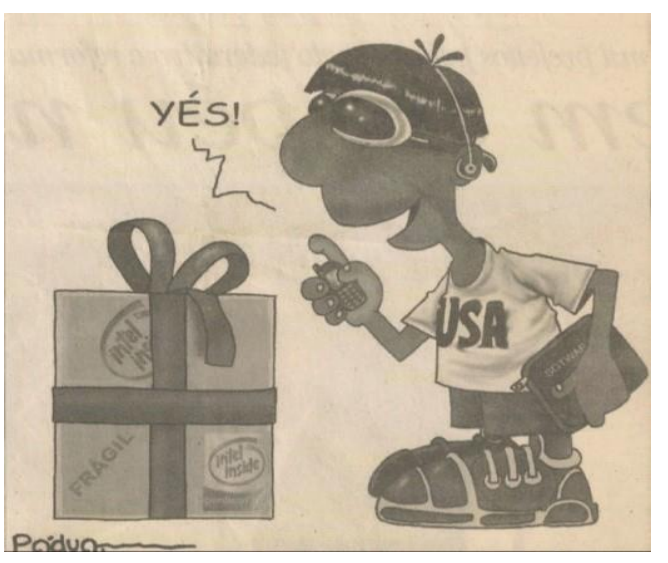

Fonte: O Popular (jul./2007).
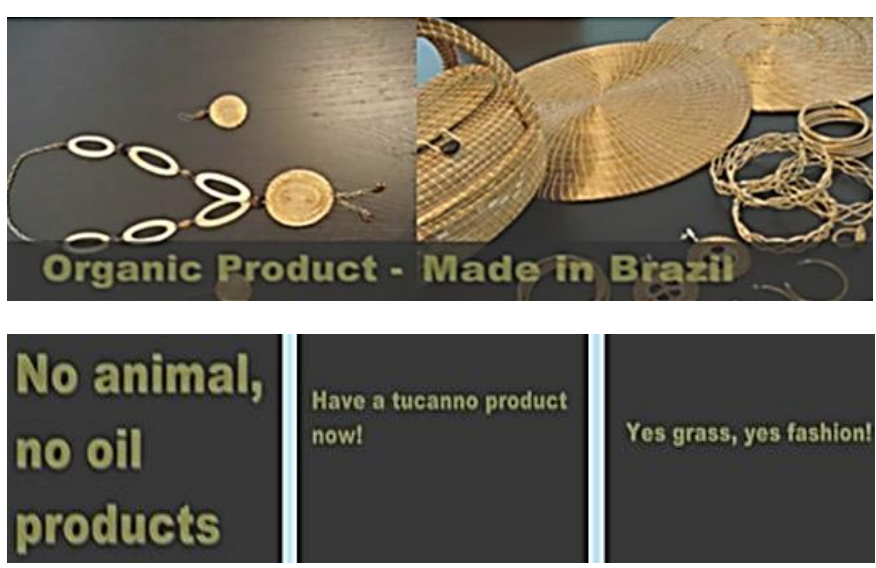

Fonte: Google (2008).

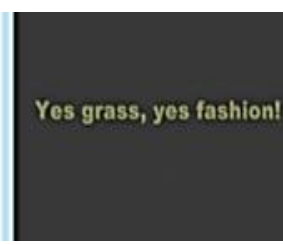

Através de gêneros textuais diversos, pautando-se na discussão de temas contextualizados, objetivamos discutir, por exemplo, sobre a propagação, venda e distribuição da arte indígena brasileira. Isso inclui, por exemplo, refletir sobre o mercado nacional e internacional dessa arte, bem como sobre o seu espalhamento na moda, na televisão e na internet.

Conforme mencionado anteriormente, além do trabalho com gêneros textuais e com temas contextuais, abordamos, ainda, o uso de alguns processos de formação de palavras comuns às línguas em contato na aula de língua inglesa, a fim de auxiliar a "leitura" em desta. Da mesma forma, refletimos sobre os sons do inglês, bem como nos engajamos na produção textual bi/tri/plurilíngue intercultural, conforme apresentado, a seguir. 


\subsection{Do contexto ao texto às palavras}

Os empréstimos linguísticos, por terem desempenhado um papel de grande importância durante o processo de leitura em língua inglesa, além de haver suscitado discussões interessantes por parte dos professores indígenas como, por exemplo, sobre os seus usos e funções em determinados contextos (cf. MELLO, 2002, em relação ao Inglês, por exemplo) e sobre seu uso cada vez maior na língua Xerente (cf. MESQUITA, 2009; BRAGGIO, 2010), dedicamos uma sessão para esse fenômeno linguístico bastante translinguístico intercultural.

Palavras emprestadas foram surgindo no diálogo de sala, como as palavras do Inglês football, beef, beefsteack e snooker, emprestadas e fonologicamente adaptadas ao Português, ao Gavião e ao Karajá: as duas primeiras ao Português, como em 'futebol' e 'bife', a terceira ao Gavião, como em bexitec ('bisteca') e, a última, ao Karajá, variando em sinu'a sinu'ka 'sinuca', a depender se se refere às falas masculina ou feminina, respectivamente ${ }^{5}$. Outros empréstimos linguísticos foram sendo apontados pelos acadêmicos indígenas nas aulas de leitura de textos em inglês como: babassu, buriti, Brazil, caju cashew, piranha piraña, caipirinha caipiriña, etc. (empréstimos para a língua inglesa via portuguesa), stock (empréstimo do francês ao inglês e ao português) e coconut (loanblend, isto é, parte da palavra é de uma língua, parte de outra). Outras palavras cognatas reconhecidas foram colour, female, natural, ornamented, dimensions, investigate, material, description, origin e quantity, palavras de origem grega e latina emprestadas ao Inglês moderno e com o mesmo significado em Português.

O Inglês é um "língua-aspiradora" (CRYSTAL, 2005, p. 15). Recebeu, ao longo da história de contato com outros povos, empréstimos de várias línguas indígenas (cf. COSTA, 2006): as da América do Sul - Tupi-Guarani (ananas, piranha, guarana, jaguar, manioc, pirarucu, caju cashew) e Quíchua (gaucho, llama, yerba, mate, pampas), além de cacique, savana, tabac, etc.; as da América Central - Náuatle (cacao, chocolate, tomate, coyote) e Caraíba (papaya, pirogue) e as da América do Norte - Ojubwa, Cheyenne, Arapaho, Esquimó (mocassim, tobogam, totem, igloo, kayak, etc.), bem como de várias outras línguas autóctones como Maori, Malaio, Tcheco, Neerlandês, Flamengo, Búlgaro, Sânscrito, além de empréstimos provindos de línguas "maioritárias", europeias e asiáticas, como o Português

\footnotetext{
${ }^{5}$ Há, na língua Karajá, diferenças entre as falas masculina e feminina como, por exemplo, a ocorrência, em determinados contextos linguísticos, do fonema $/ \mathrm{k} /$, na fala feminina, e a sua ausência na fala masculina. Para maiores esclarecimentos, ver Borges (1996).
} 
(azulejo, fado, feijoada, cupuaçu, assaí, etc.), Alemão, Holandês, Árabe, Japonês, dentre outras. (cf. COSTA, 2006).

A língua inglesa, embora seja historicamente uma língua germânica, o grosso do seu vocabulário não o é: "sua origem é em grande parte clássica e românica, com empréstimos especialmente importantes do Grego, do Latim e do Francês" (CRYSTAL, 2006, p. 38). "Isso fez com que mais da metade de seu léxico fosse formado por palavras de origem latina" (CRYSTAL, 2001, p. 40, tradução minha). O grego e o latim estão na origem de vários neologismos do Inglês formados por composição (cf. STEINBERG, 2003), os quais se espalharam e foram lexicalmente incorporados em várias línguas do mundo como, por exemplo, os morfemas gregos 'tele-' ("longe”), 'phon' ("voz”) e gramma (“carta”), os quais formam 'telefone' e 'telegrama' ou, ainda, 'neologismos' (palavras novas) cunhados a partir de morfemas ("partes de palavra") gregos e latinos, em formas de afixos (sufixos e prefixos), como bio-, eco- e psycho-, em palavras como biotecnology e ecology, formadas por três elementos greco-latinos (cf. CRYSTAL, 2006). O Inglês recebeu, ainda, diversos empréstimos linguísticos diretos do Latim (isto é, aqueles que não foram traduzidos e nem "adaptados" ao sistema linguístico do Inglês), como academia, equilibrium, album, alumnus, campus, anus, auditorium, dentre centenas de outros (cf. STEINBERG, 2003), bem como recebeu vários outros empréstimos diretos de línguas de origem latina como do Francês, principalmente, e do Espanhol, mais recentemente. Sincronicamente, o Espanhol é a língua que mais exerce influência sobre o Inglês, a ponto de substituir palavras da língua inglesa como as palavras 'pronto' (soon, em Inglês: breve; em breve), 'nada' (nothing), 'siesta' (nap: cochilo, soneca, em Português), 'fiesta' (party), 'amigo' (friend), dentre várias outras, facilmente observadas em programas televisivos norte-americanos.

Neste processo de ensino e aprendizagem das "palavras" do inglês em contexto bi/tri/plurilíngue intercultural tem sido importante pensar no conjunto lexical que formam textos (orais, escritos e semióticos) e na seleção lexical que formam os contextos de textos, bem como refletir sobre o léxico e sua formação com outras "palavras" mais lexicais (composição) ou mais gramaticais (derivação) da língua.

A partir das "palavras" que surgem nos gêneros textuais trabalhados e nos diálogos estabelecidos em sala de aula, é possível averiguar semelhanças e diferenças entre o inglês e as línguas indígenas - tanto na formação de palavras com itens mais lexicais, quando mais gramaticais. O morfema nominalizador $\{-\mathbf{k w a}\}$, da língua Xerente, por exemplo, o qual transforma verbos em nomes (com traço [+humano]), referencia-se a "alguém que realiza uma ação", o "feitor" (doer, no Inglês) dessa ação, como visto em rowahtu-kwa (ensinar-kwa) e 
teach-er (ensinar-er), significando, em ambas as línguas, "aquele que ensina", "ensinador", "professor/a". Outros morfemas que se assemelham em função e posição no Xerente e no Inglês são os nominalizadores $\{-\mathbf{z \varepsilon}\}$ e $\{$-ing $\}$. O nominalizador $\{-\mathbf{z \varepsilon}\}$ ([-humano]), conforme ocorre na palavra rowahtu-ze (ensino, escola, lugar e modo de ensinar), encontra correspondência no sufixo \{-ing\}, do inglês, transformando verbos em nomes, também com traço [-humano], como ocorre em palavras como teach-ing ("o ensino", "ensinamento"). O morfema nominalizador Xerente $\{-\mathbf{z \varepsilon}\}$ também encontra correspondência ao $\{-\mathbf{e r}\}$, do Inglês, em sua contrapartida [-humano], como ocorre em painkiller (pain: dor + kill: matar + -er: nominalizador), que seria o "mata-dor ou tira-dor", conhecido como "anador", "analgésico"

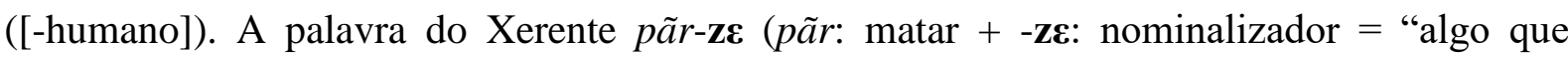

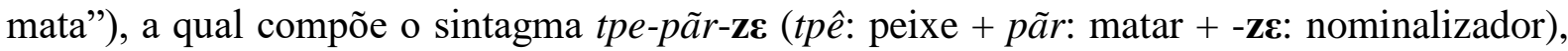
por exemplo, nos leva a observar que $\{-\mathbf{z \varepsilon}\}$ transforma verbos em nomes com traços [humanos], como no sintagma tpêpãrze ("matador de peixe"), o 'tingui', espécie de cipó venenoso utilizado para pescar (um “mata-peixe"). ${ }^{6}$

Várias similaridades e particularidades podem ser observadas entre os sistemas linguísticos das línguas Xerente, inglesa e portuguesa, o que não cabe ao escopo deste trabalho. Resta dizer que o Inglês tomou emprestado, ainda, uma série de morfemas gramaticais que desempenham papel importante na derivação de várias de suas palavras, como os prefixos $\{$ semi- $\}$ e $\{$ super- $\}$, e os sufixos $\{$-ette $\}$ e $\{-(\mathrm{t})$ eria $\}$, como em 'cigarrette' (cigarro) e $\{-(\mathrm{t})$ eria $\}$ em 'cafeteria' (restaurante) (cf. STEINBERG, 2003).

Há, assim, na língua inglesa, vários prefixos derivacionais nominais e verbais de origem latina ou grega, em sua maioria. Os prefixos derivacionais de verbos no Inglês, por exemplo, são formados a partir de morfemas como, $\{$ em- $\sim$ en- $\},\{$ re- $\},\{$ de- $\},\{$ pre- $\}$, os quais possuem equivalência no Português como em, $\{$ em- $\sim$ a- $\},\{$ re- $\},\{$ des- $\}$ e $\{$ pre- $\}$, respectivamente. Ocorrem em palavras como, empower (empoderar), enlarge (alargar), reopen (reabrir), demoralize (desmoralizar) e predetermine (predeterminar). Acrescenta-se que quase todos os prefixos do Português ocorrem no Inglês pela influência de empréstimos

\footnotetext{
6 São 11 os morfemas derivacionais do Xerente, classificados em 4 tipos: atenuativo, intensificador, nominalizador e privativo. Esses morfemas desempenham diversas funções na língua, algumas semelhantes ao inglês e ao português, e se referem, sobretudo, a tamanho, quantidade, afetividade, fases de idade, tempo cronológico, tipos de animais (peixes, aves e mamíferos), tipos de plantas, nomes de qualidade e de sensações, nomes de ação, nomes de agente, nomes de circunstância, predicados existenciais e privação. Para maiores informaç̃oes sobre derivação no Xerente, veja Cotrim e Sõpré-Xerente (2017). Para o inglês, ver Steinberg (2006) e Quirk et al (1997).
} 
latinos como, $\{$ des- $\},\{$ re- $\},\{$ sub- $\},\{$ super- $\},\{$ in- $\},\{$ ex- $\},\{$ trans- $\},\{$ ultra- $\},\{$ inter- $\},\{$ intra\}$,\{$ multi- $\},\{$ bi- $\},\{$ tri- $\},\{$ semi- $\},\{$ anti- $\},\{$ contra- $\},\{$ extra- $\}$, dentre outros. Apenas alguns são diferentes do Português como, $\{$ un- $\}$ 'negação', \{mis- $\}$ 'errado' e \{over- $\}$ 'demais'. Por outro lado, afixos como \{over-\} já se encontram no Português, como a palavra emprestada overdose. Os sufixos do Inglês são, todavia, bastante semelhantes em função com os do Português, geralmente derivando substantivos, advérbios e adjetivos.

Sufixos derivacionais de substantivos, verbos, advérbios e adjetivos mais comuns da língua inglesa em processos de formação de palavras (cf. QUIRK et al., 1997; STEINBERG, 2006), possuem correspondências com sufixos e / ou preposições do Português. Essas correspondências são: (1) Substantivos - $\{$-age $\}:\{$-deira $\} ;\{$-ance $\}:\{$-ência $\} ;\{$-er $\}:\{$-or(a) $\} ;\{$ ee $\}:\{-\operatorname{ado}(\mathrm{a})\} ;\{$-ce $\}:\{$-cia $\} ;\{$-cy $\}:\{-$ cia $\} ;\{$-ity $\}:\{$-(i)dade $\} ;\{$-hood $\}:\{$-ável $\} ;\{$-dom $\}:\{-$ mento $\} ;\{$-ing $\}:$ deverbal; $\{$-ness $\}:\{$-eza/-esa, -ice, -idade $\} ;$ (2) Verbos $-\{$-ate $\}:\{$-ar $\} ;\{$ ize $\}:\{$-izar $\} ;\{$-fy $\}:\{$-ficar $\} ;\{$-ish $\}:\{$-ir, -icar $\} ;\{$-en $\}:\{$-em, a-, ar- $\} ;$ (3) Advérbios - $\{$-ly $\}:\{-$ mente\}; \{-wise $\}:$ indica falando ou se referindo a algo; $\{$-ward(s) $\}$ : indica direção; e (4) Adjetivos - $\{-y\}:\{$-ável $\} ;\{$-al $\}:\{$-al $\} ;\{$-able $\}:\{$-ável $\} ;\{$-full $\}$ : “com” (cuidado); $\{$-less $\}$ : "sem"; $\{$-ar $\}:\{$-ar $\} ;\{$-ary $\}:\{$-ário $\} ;\{$-ic $\}:\{$-ico $\} ;\{$-ent $\}:\{$-ente $\} ;\{$-ive $\}:\{$-ivo $\} ;\{$-en $\}:\{$-ado $\}$; $\{$-ed $\}:\{$-ado $\} ;\{$-ing $\}:\{$-ante $\}$.

Palavras, partes de palavras e expressões que são encontradas em diversas línguas, com o mesmo sentido, podem ser auxiliares no ensino e na aprendizagem de línguas, favorecendo um diálogo mais sistemático das línguas em contato em um contexto de ensino bi/tri/plurilíngue intercultural. Isso quer dizer que o aluno usa o seu conhecimento bi/trilíngue intercultural para refletir sobre os usos e as funções das "palavras" na comunicação intercultural, por exemplo. Da mesma forma, observar, neste diálogo translíngue, semelhanças e diferenças dos sistemas linguísticos - tanto em seus níveis morfo-fono-sintáticos, como semântico-pragmáticos, ou seja, no que concerne ao estudo de suas palavras (processos derivacionais, composicionais e flexionais) e ao estudo dos seus sons (fonemas, sílabas, bem como as relações fonemas-grafemas), de forma contextualizada e significativa - vem se constituindo em um papel importante no ensino do inglês inserido em um contexto de diversidade de povos, línguas e (inter)culturas. Passo, portanto, à reflexão sobre o ensino dos sons neste contexto. 


\subsection{Do contexto ao texto às palavras aos sons - reflexão sobre o estudo dos sons em contexto bi/tri/plurilíngue intercultural}

Em relação aos sons das línguas com as quais trabalhamos notamos, por exemplo, que há, no Inglês, consoantes que não existem no Xerente, nem no Português. Dentre elas estão as fricativas interdentais desvozeada $/ \mathrm{T} /$ e vozeada $/ \Delta /$, como ocorre, respectivamente, no nome

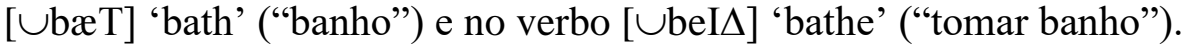

No entanto, a fricativa interdental desvozeada /T/ não é exclusividade da língua inglesa, aparecendo em algumas línguas indígenas da região Araguaia-Tocantins com as quais nos deparamos durante nossas aulas. Alguns exemplos são as palavras [Idza $\cup \mathrm{T} \square]$ 'Ijàsò'

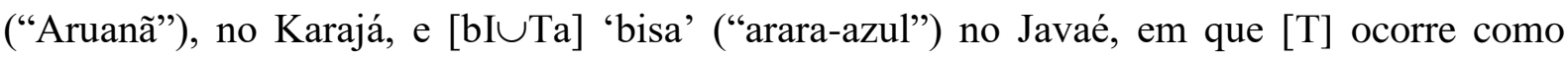
fonema nestas línguas, bem como pode ocorrer como alofone da fricativa alveolar desvozeada /s/ no Javaé (PIMENTEL DA SILVA, 2010).

Há, ainda, dois sons do Inglês que não ocorrem como fonemas nem no Português (STEINBERG, 2006), nem no Xerente: as africadas palatais (desvozeada e vozeada) $/ \tau \Sigma / \mathrm{e}$ /dZ/, como em $/ \cup \tau \Sigma i p /$ 'cheap' (barato) e / UdZæm/ 'jam' (geléia). No entanto, em diversas variedades do Português Brasileiro, $[\tau \Sigma]$ e $[\mathrm{dZ}]$ aparecem como alofones das consoantes /t/ e /d/, respectivamente, como em [ $\cup \tau \Sigma \mathrm{Ia}]$ 'tia' e [ $\cup \mathrm{dZIa}$ ' dia' (CRISTÓFARO SILVA, 2002). No Xerente, apesar da inexistência de fonemas alveolopalatais como $/ \Sigma /, / \tau \Sigma /, / 3 /$ e $/ \mathrm{dZ} /$ (cf. MATTOS, 1973), eles ocorrem no Português falado pelos Xerente (cf. ANDRADE, 2008).

De forma análoga, o fonema nasal velar /N/ do Inglês não ocorre como fonema no Português e é inexistente no Xerente. Apesar disto, ocorre na língua portuguesa como alofone da nasal alveolar /n/, encontrado antes de /k/ e /g/, como em [ $\cup$ siNku] 'cinco' e [ UsuNga] 'sunga' (STEINBERG, 2006). Além do mais, o fonema /N/ é bastante produtivo em outras línguas indígenas brasileiras como, por exemplo, no Tapirapé, ocorrendo na palavra [|r|wotfiNoo] 'yrywoxigoo' (“urubu branco”) (cf. BORGES, 2010) e na língua Gavião.

Na língua Gavião, conforme demonstram os nossos dados de sala de aula, /N/ ocorre como um de seus fonemas, tal qual no Inglês. Nas palavras do Gavião, [ $\cup n \square r]$ 'nor' (“deitar") e [ $\cup \mathrm{N} \square \mathrm{r}]$ 'ngor' (“dormir”), por exemplo, os fonemas /n/ e /N/ aparecem em um par mínimo, tais quais as palavras do Inglês [ $\cup \mathrm{kIn}]$ 'kin' (“parente”) e [ $\cup \mathrm{kIN}]$ 'king' (“rei”). 
Em relação à fricativa glotal /h/, ela é bastante produtiva no Inglês, no Xerente e no

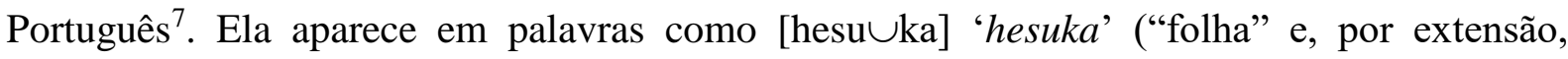

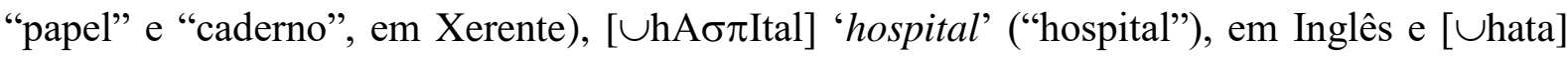
'rata', no Português. Esse fonema aparece também em todas as outras línguas indígenas da região Araguaia-Tocantins com as quais mantivemos contato no curso de Licenciatura Intercultural.

O retroflexo alveolar vozeado / $/$ é outro fonema do Inglês bastante produtivo em palavras grafadas em $r$, como em $[\cup \mathrm{r} \Theta \tau]$ 'rat' ("ratazana"), por exemplo. Apesar de não constituir um fonema do Português, há a ocorrência desse som chamado "r retroflexo" em variedades do português Tapuia, goianiense, paulista, mineiro, gaúcho, matogrossense ${ }^{8}$, em final de palavra, como em [ Umar] 'mar', e em posição final de sílaba, antes de consoante desvozeada, como em [ $\cup \mathrm{p} \square \mathrm{rta}]$ 'porta' e vozeada, como em [ $\Sigma$ ar $\cup \mathrm{mozu}]$ 'charmoso'.

No Xerente, o ' $r$ ' retroflexo não ocorre, mas há dois novos sons retroflexos que figuram nesta língua, segundo Braggio (2005) e Andrade (2008): o [*] e o [ ].$^{9}$ Em trabalho sobre o "português-xerente", Andrade (2008) considera os fones [*] e [|] como alofones alveolares fricativos (e mesmo substitutos) de / $/ \mathrm{e} / 3 /$, respectivamente (ANDRADE, 2008) ${ }^{10}$.

De forma análoga, a vibrante alveolar ou alvéolo-dental ('tepe') [r], do Português,

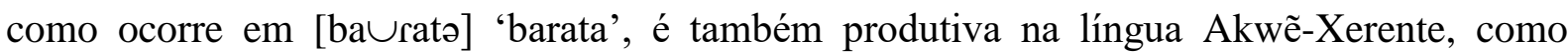
observado em [ĩ-wa $\cup$ ra] 'íwara' ("1pes-correr”), bem como em outras línguas da região Araguaia-Tocantins. Já no sistema do Inglês norteamericano, o tepe ocorre em variação e

\footnotetext{
${ }^{7}$ A fricativa glotal $/ \mathrm{h} /$ ocorre como fonema no Xerente e no Inglês. Já no Português, segundo Cristófaro Silva (2002, p. 140-142) ocorre como alofone. Seria uma ocorrência próxima à fricativa velar $/ x /$, também representada pelo arquifonema $/ \mathrm{X} / \mathrm{ou} / \mathrm{H} /$, como em ['maXa] 'marra'.

${ }^{8}$ Para um maior aprofundamento, vide Rezende (2000).

9 Ao compararmos os fones consonantais propostos por Mattos (1973) e Braggio (2005), notamos que neste último trabalho a autora acrescenta quatro novos sons que aparentemente não configuravam na língua AkwẽXerente: as nasais bilabial $[\mathrm{m}]$ e alveolar [n], a oclusiva velar $[\mathrm{g}]$ e a fricativa alveolar retroflexa desvozeada [*]. Andrade (2008) aponta, ainda, a ocorrência da retroflexa vozeada [ $\mid$ ].

${ }^{10}$ Andrade (2008) aponta que, no Português falado pelos Xerente, [*] e [l] ocorrem em variação livre, em ambientes idênticos e sem mudança de significado com as fricativas alveolopalatal desvozeada $/ \mathrm{S} / \mathrm{e}$ vozeada $/ 3 /$, respectivamente, alternando entre si sempre em início de sílaba, conforme observamos nos exemplos, a seguir:
}

(1) $\left.\left[\int\right] \sim[*]\right]$

(a) $[\mathrm{fatfi}$ 'adY] $\sim$ [*atfi'adY] 'chateado'

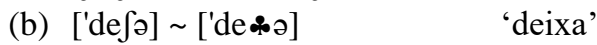

(2) $[3] \sim[1]$

(a) ['zeịtY] [ [' eitY] 'jeito'

(b) $\left[\mathrm{a}^{\prime} 3 \mathrm{Yda}\right] \sim[\mathrm{a} \mid \mathrm{Yda}] \quad$ 'ajuda' 
reflete fatores sociais (cf. LABOV, 1972), aparecendo como alofone [r] da oclusiva alveolar /t/, quando em posição intervocálica, conforme observado em [ Ubərər] 'butter' ("manteiga”) e [təumeiroY] 'tomato' (“tomate”).

Ao trabalharmos os sons consonantais do Inglês em uma perspectiva plurilíngue, percebemos que, na realidade, há apenas um único som desconhecido pelos falantes das línguas indígenas com as quais nos deparamos: a fricativa interdental vozeada $/ \Delta /$, como em [ $\cup$ bei $\Delta]$ 'bathe' ("duchar-se").

Para um falante do Português, o mesmo encontrará pelo menos seis sons (cinco fonemas e um alofone) diferentes entre esta e a língua inglesa: as fricativas interdentais, desvozeada $/ \mathrm{T} /$ e vozeada $/ \Delta /$, como em [ $\cup \mathrm{b} \Theta \mathrm{T}]$ 'bath' (banhar-se) e [ $\cup \mathrm{bei} \Delta]$ 'bathe' (“duchar-se"), respectivamente; a fricativa glotal /h/, como em [ UhaYs] 'house' (“casa"); a velar nasal /N/, como em [ Us $\square \mathrm{N}]$ 'song' (“canção"), além do retroflexo alveolar $/ \mathfrak{l}$ /, como em [ $\cup$ rein] 'rain' (“chuva”) e da lateral velar [ł], como em [ $\cup$ fił] 'feel' (“sentir”).

Segundo Cristófaro Silva (2002), no entanto, [h], [1] e [r] existem no Português como alofones. A diferença que se estabelece, então, é que, enquanto no Inglês /h/ é um fonema, no Português ocorre como alofone, como na variedade de Belo Horizonte: em posição intervocálica, como em [ $\cup$ kahu] 'carro'; em início e final de palavra, como em [ $\cup$ hata] 'rata' e [ $\cup \mathrm{mah}]$ 'mar', respectivamente; seguindo consoante em outra sílaba, como ocorre em [Isha $\cup \varepsilon w]$ 'Israel' e em final de sílaba antes de consoante desvozeada, como em [ $\cup \mathrm{t} \square \mathrm{hta}$ ] 'torta'. A velar [ł] ocorre em algumas variedades do sul do Brasil e na variante de Portugal, no final de sílaba, como em [ Usał] e [ Usałta] (cf. CRISTÓFARO SILVA, 2002). O som [r] é um alofone que ocorre somente em final de sílabas no Português, conforme demonstrado anteriormente. Já no Inglês, [r] é um tepe retroflexo que ocorre também no início de palavra, como em $[\cup$ ræt $]$ 'rat'.

Por fim, há três sons do Português que não encontram correspondência no Inglês, quais sejam, ///: "banha"; /×/: palha; e /x/: "rápido".

Em relação aos sons vocálicos, as vogais similares do Inglês, em relação às vogais encontradas nas línguas Xerente e portuguesa são: 
Xerente

\begin{tabular}{|c|c|c|c|c|c|c|}
\hline /I/ - /sI'ka/ & "galinha" & /I/ - /mInIna/ & "menina" & /I/ /'bIt/ & bit & "pouco" \\
\hline /E / - /'krE/ & "secar" & $/ \mathrm{E} / \mathrm{-} / \mathrm{pE} /$ & "pé" & /E/ /'bEt/ & bet & “apostar" \\
\hline /a/ - /da't $\square /$ & "olho" & /a/ - /'la/ & "lá" & /a/ /'faðer/ & father & "pai" \\
\hline$/ \square /$ - /ka'r $\square /$ & "arroz" & $/ \square /-/ / \mathrm{p} \square /$ & "pó" & $/ \square / / \mathrm{b} \square \mathrm{t} /$ & bought & "comprou" \\
\hline /u/ - /hu'ku/ & "onça" & /u/ - /uru'bu/ & "urubu" & /Y/ /'fYd/ & food & "comida" \\
\hline
\end{tabular}

As vogais, a seguir, da língua Xerente, também possuem correspondências com sons vocálicos das línguas inglesa e portuguesa:

\begin{tabular}{|c|c|c|c|c|}
\hline Xerente & \multicolumn{2}{|c|}{ Português } & English & \\
\hline /a/ - /am'bə/ "homem" & /a/ -/ba'nənəs/ & "bananas" & /a/ - /bə'nænə/ banana & "banana" \\
\hline /e/ - /t'pe/ "peixe" & /e/ - /'elI/ & "ele" & $/ \mathrm{e} /-/ \mathrm{de}^{\mathrm{y}} \mathrm{t} /$ & "data" \\
\hline$/ \mathrm{o} /$ - /dI' $\mid \mathrm{o} /$ "supor erroneamente" & /o/ - /'ovu/ & “ovo” & $/ \mathrm{o} /-/ \mathrm{so}^{\mathrm{w}} \supset$ & "alma" \\
\hline
\end{tabular}

Não obstante, a língua Xerente apresenta um fonema exclusivo, só dela: a vogal central alta [i] como em [krikri] "ato de lamentação fúnebre coletivo; lamentar; chorar". As "vogais" do Inglês, que diferem das do Xerente e do Português são":

\section{Inglês}

$\begin{array}{llll}/ \mathrm{aI} / * & \text { my } & \text { /maI/ } & \text { 'meu/minha' } \\ / \mathrm{Iy} / * & \text { beat } & \text { /bIyt/ } & \text { 'batida' } \\ / \mathrm{eI} / * & \text { bait } & \text { /beIt/ } & \text { 'isca' } \\ / \text { /ow/* } & \text { boat } & \text { /bowt/ } & \text { 'barco' } \\ / \text { uw/* } & \text { boot } & \text { /buwt/ } & \text { 'bota' } \\ / æ / & \text { bat } & \text { /bæt/ } & \text { 'bastão; morcego' }\end{array}$

\footnotetext{
${ }^{11}$ As vogais dos quadros marcadas com asterisco (*) são glides e vogais tensas. Para maiores esclarecimentos, consulte Cristófaro Silva (2002).
} 
Não obstante, a língua portuguesa apresenta ditongos que se aproximam dos referidos sons consonantais da língua inglesa, com exceção de $/ \Theta /$, conforme exemplos, a seguir:

\section{Português}

$\begin{array}{lll}\text { /aI/ } & \text { /saIa/ } & \text { 'saia' } \\ \text { /Iy/ } & \text { /sErIy/ } & \text { 'série' } \\ \text { /eI/ } & \text { / eeIu/ } & \text { 'cheio' } \\ \text { /ow/ } & \text { /owvidar/ } & \text { 'olvidar' } \\ \text { /uw/ } & \text { /uwtraZi/ } & \text { 'ultraje' }\end{array}$

Uma última observação em relação à língua portuguesa utilizada no contexto indígena, é que parece comum, por exemplo, que um falante Xerente escreva 'nõse' para representar o sintagma "não sei", no Português, ou 'nahu' ("na rua"). ${ }^{12}$ Isso ocorre porque o acadêmico utiliza-se de seu repertório fonológico e do seu conhecimento do sistema de escrita (sistema de representação convencional) de sua língua materna, os quais são repassados para a sua segunda língua (BORGES, 2010).

Percebe-se, portanto, que em contextos bi/tri/plurilíngues de ensino não podemos desconsiderar as relações que geralmente se estabelecem entre som e letra, pronúncia e grafia, tanto nas línguas maternas e nas segundas línguas, bem como em uma possível terceira língua que se pretende ensinar/aprender. Os acadêmicos já trazem consigo um amplo conhecimento fonológico. Exercitar a consciência dos sons das línguas neste contexto pode ser um grande facilitador de sua aprendizagem e de sua autonomia para o aprendizado da língua inglesa (cf. LAMPRECHT et al., 2009), inclusive em relação à escrita de palavras e textos em inglês, sobre a qual apresento um panorama, a seguir, a partir de uma oficina de escrita trilíngue levada a cabo durante as aulas de Inglês Intercultural.

\subsection{Do contexto ao texto às palavras aos sons, à produção textual no Inglês Intercultural}

Por mais que o enfoque do Inglês Intercultural seja o ensino e o aprendizado da "leitura", não descartamos, em nenhum momento, a produção oral e escrita nas aulas de Inglês Intercultural. Durante a última etapa - Inglês Intercultural VII, no entanto, a prática escrita foi trabalhada com maior ênfase, a partir do tema contextual Indigenous Art: E-

\footnotetext{
${ }^{12}$ Percebemos aqui que os sintagmas ' $n a h u$ ' e ' $n o \tilde{s} e$ ' são grafados de forma que se aproximam da oralidade e do conhecimento da relação som-grafema da língua materna do aluno. Ambos os exemplos são dados emergidos de atividades realizadas em sala de aula.
} 
commerce Project. A maioria dos alunos se empenhou em escrever os seus textos em inglês, bem como em suas línguas maternas, e em português.

Um exemplo da "arte final" produzida por um grupo de alunos Xerente e Gavião é demonstrado, a seguir. Esses alunos produziram etiquetas em papel-cartão as quais identificam o nome do artesanato em língua indígena e em língua inglesa, na parte frontal, e em língua portuguesa, na parte traseira. Outros detalhes da etiqueta são o slogan desenhado pelos próprios alunos e a fita de embira feita por eles mesmos para amarrar a etiqueta aos artesanatos que eles haviam trazidos das aldeias:

Figura 5 - Eh'paxüx`y - bracelet / Hapac xüxy - earring : etiquetas de pulseiras e brincos com design Krahô, Xerente e Gavião, feitos em capim dourado, semente de tiririca crua e queimada e embira (fita de buriti).

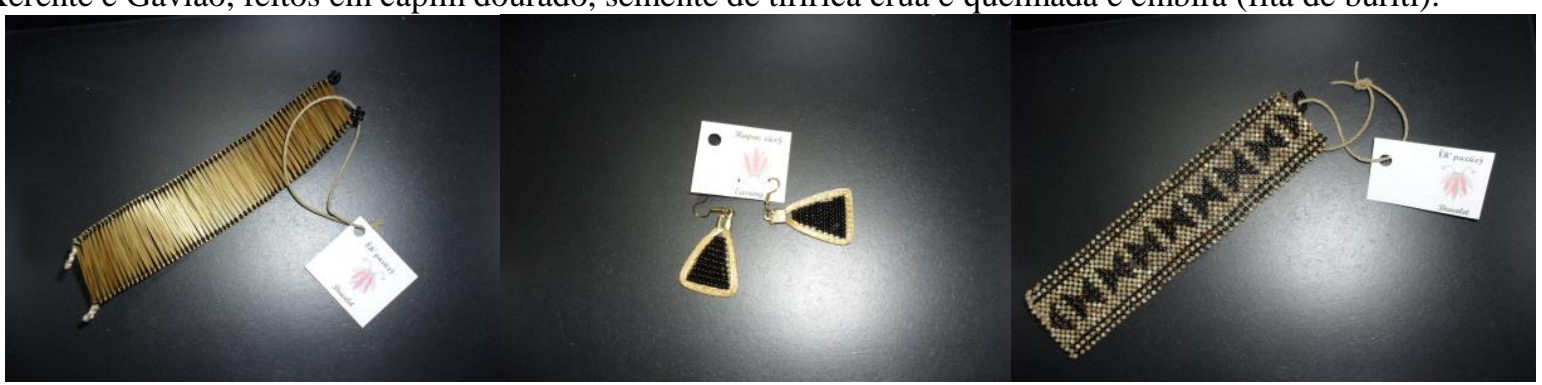

Fonte: Arquivo do autor.

Outros textos bi/tri/plurilíngues foram produzidos, geralmente utilizando-se de temáticas sensíveis aos estudantes indígenas como, por exemplo, o texto, a seguir, escrito por uma acadêmica Karajá sobre as bonecas de cerâmica, item icônico e importante da cultura desse povo: 
Su Ritxoko

Su ritxoko heka sudi relewyly re, anõmadi heka rakurimyhỹre adinade-di rakrokelaku, rexihudi tahe hekotykò rasumyhỹre, irahudi tahe hawy ky mahãdu rirtinymyhỹre.

\section{Bonecas de Cerâmica}

As bonecas Karajá são geralmente feitas de cerâmica, misturadas com cinza de madeira cega machado para não quebrar. Se faz uma fogueira para queimar a cerâmica. Depois disso, as mulheres fazem a pintura da boneca.

\section{Ceramic dolls}

The Karaja dolls are usually made of ceramic, mixing ashes of madeira cega ("blind wood") so that they don't break apart. Then, a fire is made to burn the Karaja dolls. After that, the women paint the dolls.

Autora: Melícia Wremõa de Mello Karajá

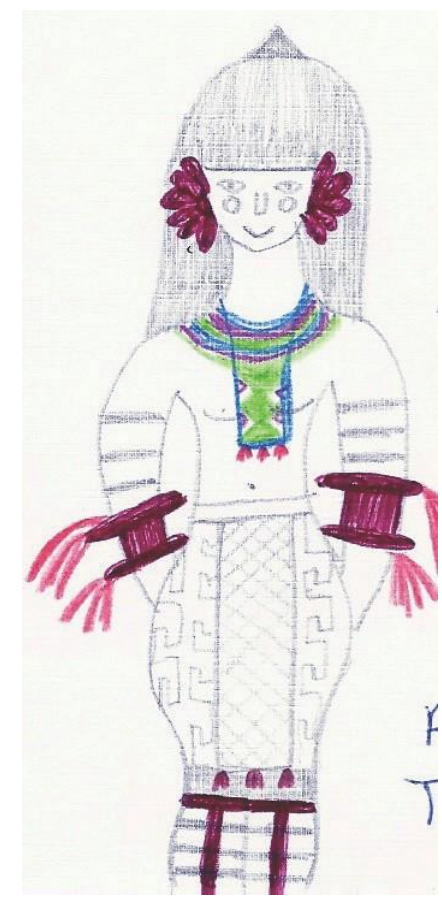

Fonte: Cotrim (2016, p. 57).

O trabalho desenvolvido no Inglês Intercultural busca protagonizar as línguas e os saberes dos professores indígenas através, por exemplo, da contextualização do conhecimento, realizado, em parte, através de temas contextuais e de gêneros textuais que dialogam a língua inglesa com a temática indígena. Esses saberes são também fundamentais para o (re)conhecimento, dentre outras coisas, das frases, das palavras e dos sons da língua inglesa - seja na leitura ou na produção de textos escritos, orais ou semióticos - mas, também, das próprias línguas maternas dos sujeitos indígenas, incluindo-se de outras variedades do português brasileiro. Essa prática do diálogo dos saberes no Inglês Intercultural, além de implicar o engajamento e o aprendizado do inglês por parte dos acadêmicos indígenas, se configura em uma motivação para a "leitura" das relações interculturais e intraculturais emergidas dentro e fora de sala de aula. 


\section{Conclu(são)(indo) ou considerações finais e pontapés iniciais}

No Inglês Intercultural, partimos do contexto ao texto, percebendo as relações interculturais em que professores e professoras indígenas são atores e autoras protagonistas desse processo. Do texto, partimos para as palavras, e destas, para o conhecimento dos sons das línguas, seguindo, assim, o continuиm proposto por Freire: do contexto ao texto, do texto à palavra, da palavra ao som.

O objetivo da elaboração de uma base de conhecimento bi/tri/plurilíngue neste contexto de ensino é intentar dialogar com o conhecimento linguístico-socio-(inter)cultural dos sujeitos indígenas envolvidos, a fim de contextualizar o processo de ensino e aprendizagem do inglês. Isso implica, necessariamente, o uso das línguas indígenas na sala de aula de Inglês Intercultural, bem como do(s) português(es) brasileiro. Esta base de conhecimento proporcionou a compreensão dos sons das línguas (Fonologia) e o conhecimento de alguns processos de formação de palavras (Morfologia) nas línguas que dialogavam no mesmo espaço pedagógico, ao passo em que trabalhávamos a "leitura" em língua inglesa. Esta base de conhecimento foi e vem sendo redesenhada e recontextualizada a cada nova etapa.

O ensino intercultural de línguas em contexto de plurilinguagens, assim como a educação bilíngue intercultural, nos coloca como desafio a aprendizagem de línguas e culturas diferentes, a sua transrelação e o (re)conhecimento da diversidade: de povos, de línguas, de culturas, de identidades sociais, de situações sociolinguísticas múltiplas, da diversidade sociohistórico-econômica dos sujeitos com os quais dialogamos. Neste sentido, a construção da base de conhecimento (pelo menos) trilíngue Xerente - Português - Inglês, foi necessária para o ensino do inglês de forma contextualizada, em um ambiente bi/tri/plurilíngue intercultural, sem uma hierarquia de línguas, sobretudo em relação ao Inglês, muitas vezes vista como língua opressora e "colonizadora".

A língua inglesa ensinada no Inglês Intercultural, no contexto do curso de Licenciatura Intercultural, foi contextualizada na sua relação intercultural com as populações indígenas da região Araguaia-Tocantins, muitas delas em contato, desde a década de 60, com falantes de língua inglesa e / ou em contato com a língua inglesa via escola, meios de comunicação e produtos de consumo. No ensino e na aprendizagem do inglês, no contexto apresentado, é possível a prática de habilidades linguístico-pedagógicas (como as de leitura, escrita e a habilidade oral), à medida em que se vai trabalhando a habilidade intercultural e 
translinguística dos sujeitos envolvidos, dentro de um conjunto de temas contextualizados nas relações interculturais e nas trocas de conhecimentos indígenas e não-indígenas.

Fazer uso das línguas dos professores e professoras indígenas nas salas de aulas de inglês é fundamental para que não se caia em um ensino descontextualizado, opressor, monolíngue e monocultural, privilegiando apenas os conceitos ocidentais não-indígenas de falar, ensinar e aprender. Exige-se, aqui, portanto, uma postura, por parte do docente, sobre um ensino politizado, menos "colonizado", visando a um diálogo crítico de metodologias, técnicas e instrumentos de ensino, e pensando na transferência de espaços de poder e de tomada de decisão de usos linguísticos (cf. HAMEL, 2003), a fim de engajar em um processo mais humano, mais democrático e menos diglóssico no ensino e na aprendizagem de línguas.

As línguas indígenas, no ensino intercultural da língua inglesa, são vistas, portanto, como "técnica de conhecimento, prática de comunicação, saber social e cultural e como instrumento de resistência", conforme afirmação de Hamel (2003, p. 258). Em outras palavras, de acordo com uma professora indígena, Nãmnãdi-Xerente ${ }^{13}$, deve-se privilegiar uma educação pautada na "construção mútua do conhecimento na língua, na cultura, na saúde, na economia, no ensino, no direito", relação baseada no respeito e no diálogo, num processo em que "um aprende a fala do outro". Um ensino que seja pautado, portanto, em conhecimentos técnicos, culturais, linguísticos e antropológicos dos indígenas brasileiros, considerando as várias formas e níveis de conhecimentos existentes, dialogando-os.

Abre-se, portanto, a possibilidade prática de se pensar em argumentos a favor do uso das línguas indígenas brasileiras (no presente caso, o das línguas dos professores Xerente, Apinajé, Canela, Gavião, Guajajara, Guarani, Javaé, Karajá, Karajá-Xambioá, Krahô, Krikati, Tapirapé e Tapuia) na educação escolar indígena, seja no ensino fundamental, médio ou superior, seja nas aulas de Inglês, de Português ou de Matemática, além de advogar pela criação de espaços públicos de uso dessas línguas tão importantes nas vidas dos professores indígenas e tão meritórias às áreas de ciências da Linguagem, da Natureza e da Cultura.

\section{Referências bibliográficas}

ANDRADE, P. H. G. Descrição e análise de alguns aspectos fonéticos e fonológicos do português falado pelos Xerente - aportes sociolinguísticos. In: IX Colóquio de Pesquisa e Extensão da UFG. Goiânia, 05 a 07 de março de 2008; Goiânia: UFG, 2008.

BORGES, M. V. Línguas indígenas e o português brasileiro: a experiência com os alunos Tapirapé. In: ROCHA, L. M., PIMENTEL DA SILVA, M. S. \& BORGES, M. V. (orgs.).

\footnotetext{
${ }^{13}$ Arquivo pessoal, Inglês Intercultural VI, Etapa na Universidade Federal de Goiás, em 03/08/10.
} 
Cidadania, interculturalidade e formação de docentes indígenas. Goiânia: Editora da UCG, 2010, p. 103-118.

As falas feminina e masculina no Karajá. Dissertação de mestrado em Letras e Linguística. Goiânia: UFG,1996.

BRAGGIO, S. L. B. Reflexões sobre os empréstimos do tipo loanblend e direto no Xerente akwén. Rev. Est. Ling., Belo Horizonte, v. 18, n. 1, p. 87-100, jan./jun. 2010.

Revisitando a fonética/fonologia da língua Xerente Akwẽ: uma visão comparativa dos dados de Martius (1866), a Maybury-Lewis (1965) com os de Braggio (2004). Signótica. Goiânia, v. 17, n. 2, 2005b. p. 251-2742

COSTA, S. C. Palavras sem fronteiras. 2. ed. Rio de Janeiro: Record, 2006.

COTRIM, Rodrigo Guimarães Prudente Marquez; SÕPRE-XERENTE, A. Morfemas derivacionais Xerente (Jê). Revista Brasileira de Linguística Antropológica: v. 9 n. 1 (2017).

Inglês Intercultural: a leitura e a escrita indígena em contexto bi/tri/plurilíngue Intercultural = Intercultural English: indigenous reading and writing in intercultural bi/tri/multilingual contexto. Goiânia: Gráfica UFG, 2016.

Akwẽ-Xerente (Jê), Português e Inglês: ensino do inglês intercultural em contexto multilíngue para professores indígenas brasileiros. Munique: Lincom academic publishers. Lincom studies in language acquisition. 31. 2012.

Perspectivas linguístico-culturais de professores-universitários indígenas no processo de ensino e aprendizagem de língua inglesa no Curso de Licenciatura Intercultural da UFG: leitura e interpretação de textos em foco. In: ROCHA, L. M., PIMENTEL DA SILVA, M. S. \& BORGES, M. V. (Org.). Cidadania, interculturalidade e formação de docentes indígenas. Goiânia: Editora da UCG, 2010, p. 169-188.

COTRIM, Rodrigo Guimarães Prudente Marquez; OLIVEIRA, C. P. Curso de formação superior de professores indígenas da UFG: translinguística, transdisciplinaridade e interculturalidade na sala de aula de Inglês Intercultural. Anais do VII Seminário de Línguas Estrangeiras. A transdisciplinaridade e o ensino das línguas estrangeiras. Goiânia: UFG, 2010. P. 367-374.

CRISTÓFARO SILVA, T. C. Fonética e Fonologia do Português. São Paulo: Contexto, 2002.

CRYSTAL, D. A dictionary of language. 2nd. ed. Chicago: The University of Chicago Press, 2001.

2005.

A revolução da linguagem. Quintana, R. (Trad.). Rio de Janeiro: Jorge Zahar Ed., How language works. England: Clays Ltd, 2006.

FREIRE, P e SHOR, I. Medo e ousadia: o cotidiano do professor. Rio de Janeiro: Paz e Terra, 1986.

FREIRE, P. A importância do ato de ler. 39. ed. São Paulo: Cortez, 2000. 
GODOY. E. La Cultura en la enseñanza del español y de las literaturas hispánicas. Anuario brasileño de estudios hispánicos, 11, 2001.

HAMEL, R. E. El papel de la lengua materna en la enseñanza: Particularidades en la educación bilingüe. In: JUNG, I. y LÓPEZ, L. E. WETZELS, W. L. (Org.). Abriendo la escuela: Linguística aplicada a la enseñanza de lenguas. Madrid: Ediciones Morata, 2003, p. 248-269.

KEHDI, V. Formação de palavras em português. 4. ed. São Paulo: Ática, 2007. Morfemas do Português. São Paulo: Ática, 2003.

KRIEGER, W. B.; KRIEGER, G. C. (Orgs.). Dicionário Escolar: Xerente-Português; Português-Xerente. Rio de Janeiro: Junta de Missões Nacionais da Convenção Batista Brasileira,1994.

LABOV, W. Sociolinguistic patterns. Pennsylvania: University of Pennsylvania Press, 1972.

LAMPRECHT, R. R. et al. Consciência dos sons da língua. Subsídios teóricos e práticos para alfabetizadores, fonoaudiólogos e professores de língua inglesa. Porto Alegre: EDIPUCRS, 2009.

LONGMAN DICTIONARY OF AMERICAN ENGLISH. New York: Longman, 1997.

MATTOS, R. Fonêmica Xerente. vol. 1. Brasília, DF: Summer Institute of Linguistics, 1973, p. $79-100$.

MELLO, H. A. B. O português é uma alavanca para que eles possam desenvolver o inglês: eventos de ensino-aprendizagem em uma sala de aula de ESL de uma "Escola Bilíngüe". 2002. 334 f. Tese (Doutorado) - Instituto de Estudos da Linguagem, Unicamp, Campinas, 2002.

MESQUITA, R. Empréstimos linguísticos do português em Xerente Akwẽ. $144 \mathrm{f}$. Dissertação (Mestrado em Linguística) - Faculdade de Letras, Universidade Federal de Goiás, Goiânia, 2009.

NASCIMENTO, A. M. Atividades de reescrita de textos numa sala de aula intercultural. In: ROCHA, L. M., PIMENTEL DA SILVA, M. S. \& BORGES, M. V. (orgs.). Cidadania, interculturalidade e formação de docentes indígenas. Goiânia: Editora da UCG, 2010, p. 133147.

Português intercultural: fundamentos para a educação linguística de professores e professoras indígenas em formação superior específica numa perspectiva intercultural. $477 \mathrm{f}$. Tese (Doutorado em Linguística) - Faculdade de Letras, Universidade Federal de Goiás, 2012.

ODLIN, T. Language Transfer. Cross-linguistic influence in language learning. Nova Iorque: Cambridge University Press, 1989/1996.

PIMENTEL DA SILVA, M. S.; ROCHA, L. M. Educação Bilíngue Intercultural entre Povos Indígenas Brasileiros. In: Revista da UFG. Goiânia: Universidade Federal de Goiás, 2006. Ano VIII, $\mathrm{n}^{\circ}$ 2. 100-105pp. 
PIMENTEL DA SILVA, M. S. A pedagogia da autonomia em educação bilíngue intercultural em contextos de formação de professores indígenas. Goiânia: UFG, 2011.

Ensino e aprendizagem de línguas numa perspectiva bilíngue. In: ROCHA, L. M., PIMENTEL DA SILVA, M. S. \& BORGES, M. V. (org.). Cidadania, interculturalidade e formação de docentes. UCG: Goiânia, 2010, p. 85-102.

QUIRK, R. et al. A comprehensive Grammar of the English language. Essex: Addison Wesley Longman Limited, 1997.

REZENDE, T. F. Discurso e identidade etnocultural na comunidade de Pombal - GO. Dissertação de mestrado. Goiânia: UFG, 2000. Inédito.

RODRIGUES, A. D. Línguas brasileiras: Para o conhecimento das línguas indígenas. São Paulo: Loyola, 1986.

SIQUEIRA, K. M. F. Aspectos do substantivo na língua xerente. 48 f. Dissertação (Mestrado em Lingüística) - Faculdade de Letras, Universidade Federal de Goiás, Goiânia, 2003.

SOUSA FILHO, S. M. Aspectos morfossintáticos da língua Akwẽ-Xerente (Jê). 330 f. Tese (Doutorado em Linguística) - Faculdade de Letras, Universidade Federal de Goiás, 2007.

SOUZA, A. G. F. et al. Leitura em língua inglesa: uma abordagem instrumental. São Paulo: Disal, 2005.

SOUZA, S. L. Descrição fonético-fonológica da língua akwen-xerente. 2008. 100 f. Dissertação (Mestrado em Linguística) - Instituto de Letras, Universidade de Brasília - UnB, Brasília, DF, 2008.

STEINBERG, M. Inglês Norte-Americano: Pronúncia e Morfologia. São Paulo: Editora Nova Alexandria, 2006.

STEINBERG, M. Neologismos de língua inglesa. São Paulo: Editora Nova Alexandria, 2003.

TUBINO, F. Entre el multiculturalismo y la interculturalidad: más allá de la discriminación positiva. In: Interculturalidad y política: desafíos y posibilidades. Ed. Norma Fuller. Lima: Red para el Desarrollo de las Ciencias Sociales en el Perú, 2005.

TUGGIA, F.R. Mappa dos Índios Cherentes e Chavantes e dos Índios Charaós na nova povoação de Thereza Christina do rio Tocantins ao norte d'esta provincia de Goyaz aldeados aos 24 de Junho de 1851. In: RIHGB, t. XIX, 1856, p. 119-124.

Submetido em 7 de outubro de 2020.

Aceito em 14 de outubro de 2020.

Publicado em 27 de outubro de 2020. 